\title{
INCREASING THE COMPETITIVENESS OF BOSNIA AND HERZEGOVINA IN THE REGION IN THE FUNCTION OF ECONOMIC DEVELOPMENT AND INTEGRATION INTO THE EUROPEAN UNION
}

\author{
Edin Arnaut ${ }^{132}$ \\ Ivan Funčić 133 \\ Amer Ajanović ${ }^{134}$
}

https://doi.org/10.31410/itema.2018.330

\begin{abstract}
The competitiveness of Bosnia and Herzegovina (BIH) in the region has had a more negative than positive trend over the past ten years. The causes for the weak competitive position of BIH and slow economic development are the result of an unstable political situation, poor business environment, incompetent and malevolent resource management, as well as the negative effects of the global economic crisis which has mainly affected small and transition countries such as BIH.

The aim of this paper is, by analyzing the key factors for BIH's weak competitiveness relative to the region, to suggest adequate guidelines and economic policy measures that are optimal for increasing the competitiveness of the BIH economy, which would ultimately contribute to economic development and accelerate the process of integration of BIH into the European Union (EU). For the purposes of this paper, the definition of competitiveness of the World Economic Forum is accepted. The methods of induction, deduction, compilation and comparative analysis were also used and on the basis of the results obtained; measures are suggested for increasing the competitiveness of BIH in the region.

The results of research suggest that the increase of the competitiveness of BIH's economy in the region is possible primarily through accelerated and continuous economic development, a structural reform of state institutions and by attracting foreign investment, which would also accelerate the process of integration into the EU. The paper also deals with the possibility of regional market integration, with the aim of attracting foreign investment, which would further increase the competitiveness of BIH in the region.
\end{abstract}

Keywords: Competitiveness, BIH, economic development, regional cooperation, EU

\section{INTRODUCTION}

In this paper, the focus is placed on the issue of increasing the competitiveness of Bosnia and Herzegovina in the region as a contributing factor to the economic development and integration into the European Union. Slow economic development and weak competitiveness of Bosnia and Herzegovina $(\mathrm{BIH})$ have been the focus of many research papers and relevant statistical analyses in recent years, confirming that the current macroeconomic indicators of BIH's economy are not at the same level with the countries in the region ${ }^{135}$. By analyzing internationally recognized scientific papers and statistical data on global competitiveness

\footnotetext{
${ }^{132}$ University of Vitez, BiH

${ }^{133}$ Faculty of Economics Rijeka, Croatia. Securitas Croatia d.o.o

${ }^{134}$ Faculty of Economics Rijeka, Croatia. Municipality of Bugojno, BiH

${ }^{135}$ Surrounding countries (region): Croatia, Serbia, and Montenegro.
} 
authors agree that the primary reasons for the slow economic development and weak competitive position of $\mathrm{BIH}$ in the region are the result of unstable political situation, poor business environment, incompetent and malevolent resource management, as well as the negative effects of the global economic crisis from 2008 which most affected small and transition economies such as $\mathrm{BIH}$. By exploring the macroeconomic indicators and the competitive position of $\mathrm{BIH}$, the authors have determined that the political and economic subsystem in $\mathrm{BIH}$, a country with approximately 3.5 million inhabitants ${ }^{136},[1]$ is not dependent solely on internal socio-economic processes but is also dependent on various external politicaleconomic influences, regional and as well as global. This perception was taken into account by the authors of this paper and their economic development premises, the propositions and the guidelines when it comes to increasing the competitiveness of $\mathrm{BIH}$ in the region.

\section{RESEARCH AIM AND METHODOLOGY}

The research aim of this paper is to analyze the key causes of weak competitiveness of BIH's economy and suggest appropriate economic policy guidelines that are optimal for increasing the competitiveness of BIH's economy in the region, which would ultimately contribute to economic development and accelerate BIH's process of integration into the European Union (EU). In accordance with the above-mentioned analysis of the research, the hypothesis of this paper is as follows: Increasing the competitiveness of BIH's economy in the region can be achieved by continuous and sustainable economic development preceded by strong institutional reforms, new strategy for attracting foreign direct investments, and a harmonized regional economic policy which would also accelerate access to EU integration.

By using the methods of comparative analysis and compilation, it is corroborated that BIH can increase competitiveness in the region when first exploiting its comparative advantages to the maximum, along with implementing institutional reforms and new strategies for competitiveness that would create preconditions for sustainable economic development, thereby fulfilling one of the key criteria for integration with the EU. Moreover, by using methods of induction and deduction, the possibility of regional integration of the market is also discussed and problematized with the aim of attracting foreign investments which would, by their capacity, additionally increase global competitiveness of BIH as well as other countries in the region. However, the question arises as to whether this type of market integration in the region is possible considering the mutual distrust of countries that have not yet achieved a common political and economic consensus since 1995.

\section{ANALYSIS OF THE COMPETITIVENESS OF THE BIH ECONOMY}

In the literature there are a greater number of definitions of the competitiveness of the economy. The definition adopted in this paper is that of the World Economic Forum ${ }^{137}$ where competition is defined as a set of institutions, policies, and factors which determine the levels of productivity of a country. The World Economic Forum bases its competitiveness analysis on the Global Competitiveness Index, a comprehensive framework measuring the microeconomic and macroeconomic fundaments of national competitiveness consisting of 114 indicators grouped

\footnotetext{
${ }^{136}$ United Nations, Department of Economic and Social Affairs, Population Division (2017). World Population Prospects: The 2017 Revision, Key Findings and Advance Tables. pp.17

137 The World Economic Forum is an independent international organization founded in 1971, headquartered in Geneva, Switzerland. This nonprofit organization is committed to the improvement of the economies of the countries in the world by including business, political, academic and other leaders of society in order to shape global, regional and industrial strategies.
} 
in 12 pillars ${ }^{138}$ [2]. By researching various sources and statistical data from international organizations and domestic state agencies as well as meritorious scientific papers on BIH's regional competitive position, the main causes for BIH's weak competitive position in the region were identified. Taking into consideration data on slow economic development of BIH since 2008, political instability and unfavorable business environment ${ }^{139}$, the authors corroborated the current weak competitive position of BIH in the region.

According to the Global Competitiveness Report 2017-2018, [3] BIH is ranked as $103^{\text {th }}$ with a score of $3,87^{140}$ in the Global Competitiveness Index using quantitative methods and survey data by combining 114 development indicators allotted to the previously mentioned 12 pillars of competitiveness. Relative to the region, $\mathrm{BIH}$ is at the back with regard to competitiveness, which is evident in Table 1. It is important to note that the Global Competitiveness Index takes into account three stages of development (factors phase, efficiency phase, and innovation phase) through which each country passes depending on the influence of all the 12 pillars of competitiveness. Bosnia and Herzegovina is in the second stage of development together with 31 other counties, which should be both stimulating as well as risky when deciding on the strategy for which increasing competitiveness is at stake, especially in relation to the countries in the region which should be preceded by accelerated economic development.

Table 1: Competitiveness rank of BIH and other countries in the region for period 2008-2017

\begin{tabular}{|c|c|c|c|c|c|c|c|c|}
\hline Year & $\begin{array}{c}\text { Total } \\
\text { countries }\end{array}$ & Albania & BIH & $\begin{array}{c}\text { Monte- } \\
\text { Negro }\end{array}$ & Croatia & Macedonia & Slovenia & Serbia \\
\hline & & & & & & & & \\
\hline 2008 & 134 & 108 & 107 & 65 & 61 & 89 & 42 & 85 \\
\hline 2009 & 133 & 96 & 109 & 62 & 72 & 84 & 37 & 93 \\
\hline 2010 & 139 & 88 & 102 & 49 & 77 & 79 & 45 & 96 \\
\hline 2011 & 142 & 78 & 100 & 60 & 76 & 79 & 57 & 95 \\
\hline 2012 & 144 & 89 & 88 & 72 & 81 & 80 & 56 & 95 \\
\hline 2013 & 148 & 95 & 87 & 67 & 75 & 73 & 62 & 101 \\
\hline 2014 & 144 & 97 & - & 67 & 77 & 63 & 70 & 94 \\
\hline 2015 & 140 & 93 & 111 & 70 & 77 & 60 & 59 & 94 \\
\hline 2016 & 138 & 80 & 107 & 82 & 74 & 68 & 56 & 90 \\
\hline 2017 & 137 & 75 & 103 & 77 & 74 & - & 48 & 78 \\
\hline
\end{tabular}

By analyzing the pillar values individually, it is observable that BIH has incrementally improved results in a number of areas, which is evident in the following (Figure 1):

\footnotetext{
138 Pillars of competitiveness: 1) Institutions, 2) Infrastructure, 3) Macroeconomic Environment, 4) Health and Primary Education, 5) Higher Education and Professional Training, 6) Efficiency of the Commodity Market, 7) Labor Market Efficiency, 8) Financial Market Development 9) Technological readiness, 10) Market size, 11) Business sophistication and 12) Innovation.

${ }^{139}$ In Doing Business Report 2018 (World Bank), BIH is ranked as $86^{\text {th }}$ for ease of doing business

${ }^{140}$ According to the precise calculation methodology, which is the same throughout the world, the average score is comprised of the 12 pillars of competitiveness. Relevant macroeconomic statistics are taken in order to calculate the indicators after which grades from 1-7 are assigned to each indicator.
} 
Figure 1: Index of competitiveness for BIH rank on 12 pillars 2017-2018

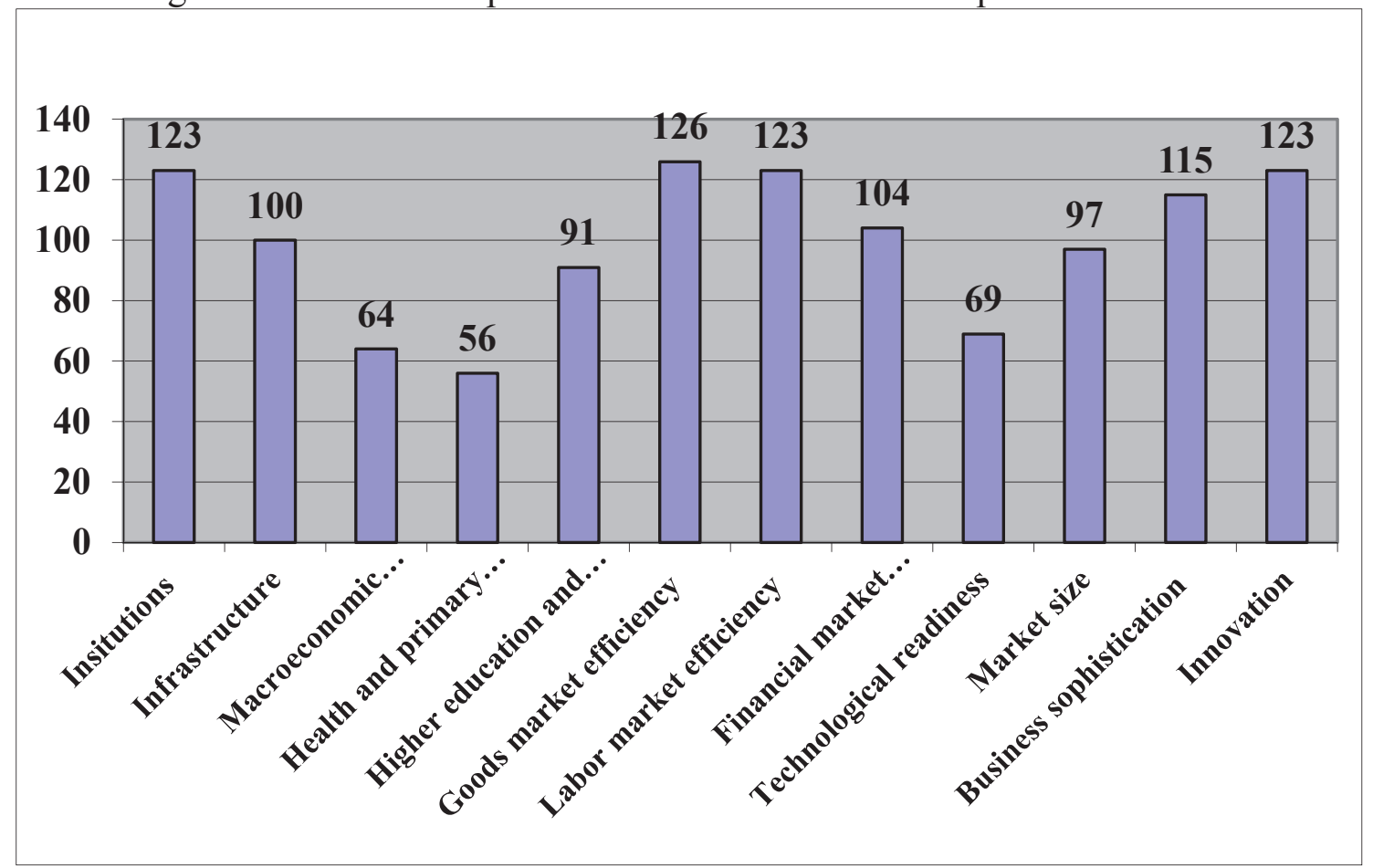

Source: Edited by authors on the basis of the Global Competitiveness Report 2017-2018 [2]

Most areas have recorded slight progress, but final evaluations did not change much as other countries advanced faster than BIH. The unchanged spot relative to previous periods (years) was recorded for the pillar Institutions $\left(123^{\text {rd }}\right)$, business sophistication $\left(115^{\text {th }}\right)$, and innovation $\left(123^{\text {rd }}\right)$. From the above, when the competitiveness of BIH is at stake, the weaknesses of the $\mathrm{BIH}$ economy are evident relative to the region, and on the basis of these findings the decision makers, prior to making of the economic development and competitiveness strategy need to work expeditiously to solve the problems of dysfunctional institutions, inefficient markets for goods and labor, outdated infrastructure, business unsophistication [4] and insufficient innovation in order to create the preconditions for sustainable economic development and thus increase the competitiveness of the BIH economy.

\section{GUIDELINES FOR INCREASING THE COMPETITIVENESS OF BIH ECONOMY}

An interconnection and interdependence of the previously mentioned 12 pillars of competitiveness has been identified. It is important to note that the indices of the pillars of competitiveness are also dependent on the indicators of country development such as GDP per capita and the capacity of natural and human resources [5], which led to conclusion that the current competitive position of BIH requires a clear and precise economic development strategy and competitiveness in which decision-makers at the national level will adopt proposals based on empirical research, specifically on the basis of applied strategies previously implemented in smaller transition countries such as BIH.

In accordance with the presented and in line with the Competitiveness Index for Bosnia and Herzegovina for 2017-2018 (Table 1), the authors suggest - in order to create preconditions for increasing competitiveness - urgent reconstruction of existing infrastructure, reform of institutions along with relaxation of political relations, harmonization of regulation of goods and labor markets with EU standards, improvement of business sophistication as well as the development of special innovation strategy. It is completely clear that $\mathrm{BIH}$, by accelerating the 
economic development in accordance with individual development and competitiveness strategies, will become a more competitive, that is, more successful economy in the region in the long term. The only appropriate question is, in which timeframe is it realistic to do so? This is a key issue because at present the BIH economy is lagging behind the countries in the region, especially when it comes to Croatia as an EU member, but Serbia and Montenegro as well, which have EU candidate status.

It is evident that many reforms and changes in development strategies lie ahead of BIH when it comes to increasing its competitive position in the region. It is important to note that BIH is still awaiting its candidate status in the EU, and for this reason, it is inevitable to observe BIH's competitiveness in a global context, that is, within the framework of EU integration, not only regionally. [6] In the context it is important note that BIH should not limit itself to increasing competitiveness in the region, but it is necessary to harmonize the regulations on export and import of goods and labor markets with the EU so as to create conditions for attracting foreign investments from dominant economies such as Germany, Austria, and Italy.

In accordance with the Global Competitiveness Report 2017-2018 (World Economic Forum) unlike with other transition countries, the authors agree that the following factors have a particularly strong impact on increasing BIH's competitiveness:

I. Domestic and foreign investments, ${ }^{141}$

II. Business sophistication,

III. Technological readiness and innovations.

In order to correctly identify the connection and dependence among these factors as well as among the 12 pillars of competitiveness, the authors suggest, for further research, the use of a complex method of correlation analysis by which the correlation value would be determined by a correlation coefficient, the value of which would range from -1 to +1 (Figure 2). According to Vuković (2013), this method has confirmed that there is interdependence between certain indicators and regional competitiveness factors, especially in investments in science, technology and innovation and in improving the business environment, which is directly related to increasing competitiveness. [7]

Figure 2. The scale of correlation

\begin{tabular}{|c|c|c|c|c|c|c|c|c|c|c|}
\hline & $\begin{array}{c}\text { Strong } \\
\text { negative }\end{array}$ & & & $\begin{array}{c}\text { Weak } \\
\text { negative }\end{array}$ & $\begin{array}{l}\text { Negligible } \\
\text { correlation }\end{array}$ & $\begin{array}{c}\text { Weak } \\
\text { positive }\end{array}$ & & & $\begin{array}{c}\text { Strong } \\
\text { positive }\end{array}$ & \\
\hline-1 & $-0,8$ & $-0,6$ & $-0,4$ & $-0,2$ & 0 & 0,2 & 0,4 & 0,6 & 0,8 & 1 \\
\hline
\end{tabular}

Source: Edited by authors on the basis of Vuković, D. (2013) [7]

It is important to point out that the authors are cautious when it comes to the guidelines for increasing competitiveness only by individual pillars because it is precisely due to their interdependence the question arises as to whether a country's competitive index can grow in continuity in this way?

Analyzing the competitive position of other countries in the region, especially Croatia and Serbia, the authors confirmed that the previously mentioned factors also have a significant impact on their competitiveness as they are countries with similar economic potential and natural resources, human capacity and capital [8]. It is for that exact reason that the authors

\footnotetext{
${ }^{141}$ It refers to domestic investment in production capacities, new technology and human resources (investment in education and professional training)
} 
believe that the integration of the regional market with the aim of attracting foreign direct investments would increase the regional and global competitiveness of $\mathrm{BIH}$.

\section{RESULTS}

Interdependence of economic development, competitiveness and BIH integration process in the EU has been confirmed on the example of BIH's competitiveness in the region. The strategy for increasing the competitiveness of the BIH economy should be observed in this context as it is not enough for a country to be successful or competitive by development indicators or pillars of competitiveness only, as each of them has a different degree of influence on the economic development and integration process in the EU. For instance, by using the methods of induction and deduction, the authors obtained the results that only institutional reform or improving business sophistication will not significantly increase the overall levels of competitiveness of $\mathrm{BIH}$ in the region. Taking into consideration the financial and capital constraints of BIH with regards to investing in development and strategies for new technologies and innovations, [9] Bosnia and Herzegovina can solve this problem by external borrowing (in the short-term) or with new strategy for attracting foreign investments from economically more dominant EU countries (in the long-term).

The final research results in this paper point out and confirm that increasing the competitiveness of the BIH economy in the region can be achieved in a relatively short period through accelerated and continuous economic development, with the structural reform of state institutions, by improving business sophistication, attracting foreign investments and investing in innovation. However, by analyzing the interconnection between the 12 pillars of competitiveness and then the individual development indicators it is confirmed that in the long term BIH cannot significantly increase its competitiveness in the region unless it observes competitiveness in its strategy as a complex whole in which each factor and development indicator can have a positive or negative implications. In this context it is important to note that the key role in implementing the new strategy of development and increased competitiveness should be given to reliable strategic investors and private sector leaders [10] who have the capacity to innovate, invest, and produce a quality good which would facilitate BIH's access on the regional and global market.

\section{CONCLUSION}

From the analysis of the report on global competitiveness it is evident that Croatia, Serbia, and Montenegro have succeeded in increasing their overall global competitiveness indices relative to $\mathrm{BIH}$, although not for all individual competitiveness pillars, which is a great opportunity for $\mathrm{BIH}$. In that context the authors agree that examples from countries in the region, can serve as a guideline and guidance in improving the macroeconomic indicators of development and increasing competitiveness of $\mathrm{BIH},[11]$ and in particular that applies to the example of Croatia and Serbia which are currently showing great results in attracting foreign investments.

The current weak competitive position of $\mathrm{BIH}$ in the region is clearly observable. By analyzing the global competitiveness index for BIH, it is estimated that, in the future, the BIH economy can become more competitive in the region only if in the upcoming period develops faster than the surrounding countries (Croatia, Serbia, and Montenegro). The future harmonization of regional market policy and the emphasis on creating an integrated market space, with the aim of attracting foreign direct investments, would certainly further strengthen BIH's competitive position, which at this moment is not realistic. The authors are of the opinion that increasing 
the competitiveness of $\mathrm{BIH}$ and regional market integration, should be one of the main topics for future discussions and scientific papers on the global level, which would certainly help economic policy makers in this region to improve the global competitive indices of their respective countries based on the empirical research findings and proposed guidelines in their new development strategies.

\section{REFERENCES}

[1] Accessed: https://population.un.org/wpp/Publications/Files/WPP2017 KeyFindings.pdf

[2] [3] Schwab, K. (Ed.) (2017) The Global Competitiveness Report 2017-2018. World Economic Forum. Geneva. Accessed:http:/www3.weforum.org/docs/GCR20172018/05FullReport/TheGlobalCompetitivenessReport2017\%E2\%80\%932018.pdf

[4] World Bank (2018) Doing Business 2018: Reforming to Create Jobs. Washington, DC: World Bank. DOI: 10.1596/978-1-4648-1146-3. License: Creative Commons Attribution $\begin{array}{lllll}\text { CC } & \text { BY } & 3.0 & \text { IGO. }\end{array}$ http://www.doingbusiness.org/content/dam/doingBusiness/media/AnnualReports/English/DB18-print-report.pdf

[5] World Bank Group (2018) Western Balkans regular economic report: Higher but fragile growth No.14. fall 2018 . Accessed:

http://pubdocs.worldbank.org/en/194301538650996304/rev2-WBRER14-WQ-web-ENG.pdf

[6] Huggins, R. and Thompson, P. (2017) Handbook of regions and competitiveness: contemporary theories and perspectives on economic development. Cheltenham: Edward Elgar.

[7] Vuković, D. (2013) "Correlation analysis of indicators of regional competitiveness: The case of the Republic of Serbia" Economic Horizons, 2013, Vol. 15, No. 3, pp. 201-215.

[8] Džafić, Z. (2011) Competitiveness of BiH economy in function of European Integration Second International conference "Economy of integrations", Faculty of Economics, Tuzla

[9] Vujović, D. (2014) "Western Balkans Regional R\&D Strategy for Innovation" In Marinkovic, I., Dall, E. ed., $R \& D$ and Innovation in Western Balkans: Moving Towards 2020, Wien: WBC-INCO.NET c/o ZSI - Centre for Social Innovation.

[10] [11] European Commission (2018), “Bosnia and Herzegovina 2018 Report”, pp. 34-39. Accessed: https://ec.europa.eu/neighbourhood- enlargement/sites/near/files/20180417bosnia-and-herzegovina-report.pdf 